\title{
NLRP4 Antibody
}

National Cancer Institute

\section{Source}

National Cancer Institute. NLRP4 Antibody. NCI Thesaurus. Code C111809.

Any immunog lobulin that recognizes NACHT, LRR and PYD domains-containing protein 4. 